\title{
EX-Post REDISTRIBUTION IN A FEDERATION: IMPLICATIONS FOR CORRECTIVE POLICY
}

\author{
MARKO KOETHENBUERGER
}

\section{CESIFO WORKING PAPER NO. 1754 \\ CATEGORY 1: PubliC FinANCE \\ JULY 2006}

\footnotetext{
An electronic version of the paper may be downloaded

- from the SSRN website:

www.SSRN.com

- from the RePEc website:

Www.RePEc.org

- from the CESifo website:

www.CESifo-group.de
} 


\title{
EX-POST REDISTRIBUTION IN A FEDERATION: IMPLICATIONS FOR CORRECTIVE POLICY
}

\begin{abstract}
This paper analyzes whether changes in the timing of equalizing transfers to state governments necessitate an adjustment in federal corrective policy. According to the existing literature (assuming an ex-ante choice of transfers), the corrective grant is equal to the marginal damage/benefit inflicted by externality generation. When the federal government accommodates state finances ex-post, the grant differs in formula from existing prescription. Allocative federal policy corrects state policy incentives twofold. It entails a correction for the distortion in the marginal benefit of state spending (as in earlier literature) and for the distortion in the marginal cost of public funds induced by the ex-post provision of transfers. The required grant rule is generically disproportionate to the equilibrium externality (even with lump-sum taxation). Furthermore, the ex-post provision of transfers is critical for the nature of the equilibrium inefficiency. Equalizing transfers at least partly internalize consumption spill-overs, but simultaneously establishes a new source of inefficiency. As a final result, the existing prescription for allocative federal policy continues to apply if the public good is pure.
\end{abstract}

JEL Code: H7, D62, H3, H1.

Keywords: federalism, externality, corrective grant, equalization, commitment.

Marko Koethenbuerger
Center for Economic Studies and CESifo
at the University of Munich
Schackstr. 4
80539 Munich
Germany
mkoethen@ces.vwl.uni-muenchen.de

A previous version of the paper circulated under the title "Federal Commitment, Externalities, and Corrective Grants". I am grateful for comments by seminar participants in Dortmund, Munich, Nürnberg, at the CESifo conference "Public Sector Economics" (Munich, 2004), at the Canadian Public Economics Group meeting (Toronto, 2004), at the IEB workshop "Fiscal Federalism" (Barcelona, 2005), at the PET conference (Marseille, 2005), the Tjalling C. Koopmans workshop "International Policy Competition and Coordination" (Utrecht, 2005) and at the IIPF meeting (Jeju, 2005). Comments by Richard Cornes, Robert Dur, Laszlo Goerke, Andreas Haufler, Susana Peralta, Panu Poutvaara, Mikael Priks, Wolfram Richter, Hirofumi Shibata, Berthold Wigger, and in particular by Sören Bo Nielsen are gratefully acknowledged. 


\section{Introduction}

Federal policy towards local governments involves both a corrective and a redistributive role. Tax and expenditure decisions of local governments typically fall short of reflecting all costs and benefits associated with them, thereby creating demand for corrective federal policies. The federal government is moreover engaged in fiscal equalization, most notably motivated by the idea that households should have access to comparable levels of public service at comparable tax prices irrespective of their place of residence within the federation. ${ }^{1}$

In an ideal world, equalizing transfers are provided as lump-sum payments. In practice, however, fiscal equalization affects local policy incentives. Equalization policy is primarily based on a transfer formula. Entitlement payments are made dependent on the capacity of local governments to provide a sufficient level of public services to the constituency. A second reason as to why federal redistribution changes local policy incentives, is that the federal government at least partly decides on equalizing transfers ex-post, i.e. after local governments have supplied public services. ${ }^{2}$ When these outcomes compromise national equity objectives, the federal government may extend resources beyond the amount it was prepared to provide ex-ante. ${ }^{3}$ Ex-post equalization biases local policy choices towards policy bundles, which lure a larger amount of transfers to their budgets. The fiscal importance and incentive effects of ex-post transfer policy have received increasing attention in the recent literature on public finance which documents empirical evidence consistent with the prediction of a strategic choice of local policy (see Kornai et al. (2003) for a review). ${ }^{4}$

\footnotetext{
${ }^{1}$ The underlying notion of a "social citizenship" is entrenched in the constitution of Canada, Germany and South Africa. In the U.S. formal equalization systems are most notably confined to the equalization of community school expenditures. They are motivated by the principle of "equal opportunities" which is related to the notion of a "social citizenship".

${ }^{2}$ To relate ex-post redistribution to the notion of renegotiation, note that the latter requires unanimity among all public entities involved (Salanie, 1997). Evidently, ex-post redistribution does not innately qualify as a renegotiation. At least one region will object to the ex-post adjustment of transfers. As such, the ex-ante announced allocation of equalizing transfers satisfies the requirement of renegotiation-proofness, meaning that some, but not all, may agree to depart from it. Typically, ex-post redistribution is accomplished by the coercive power of the federal government.

${ }^{3}$ The two forms of fiscal equalization can be thought of as being borne out of the same policy principle, but contribute to its implementation in a hierarchical order. Fiscal capacity equalization gives localities the potential to provide an appropriate level of public services. If the selected amounts still substantially differ, thereby compromising the idea of a "social citizenship", the federal government may provide transfers additionally. The ex-post provision of transfers may be legislatively decided or court-ordered. For instance, enforcing the constitutionally-anchored "grandfathering" role the German supreme court instructed transfers to the states of Bremen and Saarland beyond the amount received via the formulaic pilar. A upcoming recipient state is Berlin, which, following a supreme court's ruling, is expected to receive a bailout in 2007.

${ }^{4}$ For instance, Rodden et al. (2003) present evidence on the adverse effects of ex-post transfer policy in major federal countries (including the U.S., Canada, and Germany). Zhuravskaya (2000) shows that Russian cities reduce
} 
In this paper we analyze whether incentive effects in ex-post redistribution concern the nature of federal corrective policy. Concretely, under what circumstances can we expect corrective policy to be sensitive to the timing of transfers? The analysis indicates that ex-post equalization policy has a bearing on corrective policy. The general prescription that the optimal grant features a subsidy on the marginal externality continues to hold. However, both the foundation of the subsidy and the nature of the externality are affected by the timing of equalizing transfers. ${ }^{5}$ As to the externality, when strategically setting tax and expenditure levels, each state's policy influences the ex-post allocation of transfers nationwide. The incentive effect translates into a fiscal externality on neighbor states. The transfer induced externality and the consumption spill-over do not additively identify the equilibrium externality. A state at least partly internalizes the consumption spill-over on neighbor states when seeing through the federal government's transfer policy, ameliorating the efficiency of state policy. ${ }^{6}$ Both layers of governments benefit from renegotiating the initial transfer scheme so as to include an explicitly corrective pilar. ${ }^{7}$ The incentive effects of ex-post redistribution are different to the finding in Caplan et al. (2000). When the federal transfer policy addresses disparities in private per-capita income and public consumption is pure, ex-post redistribution yields an exact counterbalancing of the transfer-induced externality and the consumption spill-over. ${ }^{8}$ In the present paper, redistribution takes place in public funds and public consumption may exhibit any degree of rivalry. In such an economy, both types of inefficiencies do not counterbalance. They may in fact be of the same sign.

A second finding relates to what would be the optimal subsidy in the corrective grant rule. In

local tax rates anticipating that tax revenues will be "taxed" by the center in the form of less transfers. Also, Swedish municipalities recurrently received bailouts from the federal level. The expectation to qualify for additional federal funds increased public debt levels by 6-10 percent in municipalities which expected to receive ex-post transfers (Dahlberg and Pettersson-Lidbom, 2003). In the U.S. context Buettner and Wildasin (2006) present empirical results consistent with the idea that that recipient governments can induce higher ex-post fiscal transfers from donor governments through their own policy actions.

${ }^{5}$ In the underlying economy the existing prescription implies the following: $(i)$ The rationale of corrective policy is to internalize consumption spill-overs. (ii) The corrective grant reflects the marginal consumption spill-over. Moreover, when lump-sum taxes are available, the grant rule is proportional to the externality, i.e. the subsidy is equal to unity - a result frequently referred to as "Pigouvian taxation".

${ }^{6}$ The effect appears to be reminiscent of "seeing through" the federal budget (Bernheim, 1986, and Boadway et al., 1989). The absence of federal commitment conceptually differs from the former as it additionally requires to "see through" the federal optimizing behavior as laid down by the federal first-order conditions.

${ }^{7}$ Thereby, the economy operates on the Pareto-frontier; rendering the grand fiscal scheme (redistributive and corrective transfers) renegotiation-proof (Salanie, 1997).

${ }^{8}$ The efficiency result has greatest relevance when preferences are symmetric (Chiappori and Werning, 2002). 
the existing literature it amounts to the inverse of the social marginal cost of public funds; so as to induce the socially efficient provision of the externality. The prescription becomes inappropriate with ex-post redistribution. The difference in results reflects the fact that the locally perceived marginal cost of public expenditures is biased by the ex-post redistributive policy. As a corrective measure, the subsidy is adjusted to offset the price bias in local spending, thereby consistently deviating from the inverse of the social marginal cost of public funds. From the analysis we can conclude that the optimal grant formula corrects local policy twofold: it corrects the distortion in the marginal benefit of state spending (externality) and the distortion in the marginal cost of public funds.

An important special case arises when local governments contribute to a pure public good. Federal corrective policy becomes independent of the timing of equalizing transfers (ex-ante vs. ex-post). The rationale is that the ex-post allocation of transfers leaves public good consumption in each state unchanged and, as such, insulates state policy choices from how the federal government reacts ex-post. As suggested by the existing literature, the optimal corrective grant tags the marginal consumption spill-over weighted by the inverse of the social marginal cost of public funds.

The paper is closely related to the literature on fiscal federalism which in most parts invokes the assumption of federal policy commitment (e.g. Gordon, 1983 and Dahlby, 1996). Recent contributions relax the premise of an ex-ante choice of transfer policy. Therein, a common conclusion is that, expecting to qualify for ex-post transfers, state governments choose a suboptimal level of public expenditures and taxes (e.g. Wildasin, 1997, Bordignon et al., 2001, Goodspeed, 2002, Boadway et al., 2003, Akai and Sato, 2005, and Boadway and Tremblay, 2005). ${ }^{9}$ The literature provides a comprehensive treatment of the incentive effects of ex-post redistribution, but does not analyze the implications for federal corrective policy.

A straightforward question relates to the relevance of the results when considering formulaic transfers in addition. There are contributions which recognize the virtue of equalization payments to improve state policy incentives. Formula-based equalizing schemes internalize effects on the tax base of other states which, for instance, arise in state competition for mobile resources

\footnotetext{
${ }^{9}$ In second best the commitment failure may have positive welfare effects. It undermines (ex-ante) inefficient incentives to bail-out firms (Qian and Roland, 1998) and limits welfare-reducing competition for mobile capital (Köthenbürger, 2004).
} 
(e.g. Köthenbürger, 2002, and Bucovetsky and Smart, 2006). ${ }^{10}$ As shown in an extension, when formula-based equalization and ex-post redistribution is undertaken simultaneously, the formulabased equalization program is neutral for state policy choices and the implications for corrective policy presented so far apply.

The paper contributes to the literature on optimal taxation in the presence of externalities. The insight from the literature is that, in a second-best setting, the optimal tax on the externality generating activity is not strictly Pigouvian, i.e. disproportionate to the external damage or benefit. The corrective part of the optimal tax may deviate from the externality when taxation is distortionary (Sandmo, 1975, and Bovenberg and van der Ploeg, 1994), when asymmetric information restricts public policy (Cremer et al., 1998), when market structures are imperfectly competitive (Barnett, 1980) and when multiple levels of government provide public goods (Akai and Ihori, 2002 $)^{11}$. In second-best environments the optimal grant induces an incomplete correction of the externality. The paper offers a refined view of how the optimal grant structure relates to the amount of spill-overs corrected in equilibrium. The commitment failure does not delineate a second-best environment with the well-established properties of corrective policy. The ex-post provision of transfers demands a deviation from the strictly Pigouvian grant structure - even with lump-sum taxes. However, with the latter mode of financing, the deviation is compatible with a full correction of the external effect. Extending the analysis to include distortionary tax financing, the deviation yields an under-correction of the marginal externality (as in Sandmo, and Bovenberg and van der Ploeg), but unlike the general insight it may be accomplished by over-representing the external effect in the grant rule.

Also related is the recent work on the use of optimal corrective policy to address a bias in consumption choices (e.g. Krussel et al. (2005)). The work does not discuss optimal policy towards a spending bias in fiscal federalism. ${ }^{12}$

\footnotetext{
${ }^{10}$ Equalization also has a bearing on the efficiency of migration decisions (Boadway and Flatters, 1982, and Mitsui and Sato, 2001). Unlike Boadway and Flatters, Mitsui and Sato allow private agents to make their migration decisions prior to policy formation. In both papers the assumption on intergovernmental commitment follows the traditional top-down commitment approach.

${ }^{11}$ The paper resorts to a pre-commitment ability by the federal government. The deviation from the traditional rule arises in environments in which the federal government does not optimize over the complete set of policy variables at hand.

${ }^{12}$ The archetypical situation analyzed is that individuals suffer from a commitment problem which leads in overconsumption. Besides taking up the issue in the context of fiscal federalism, the source of the spending bias differs in our formulation. The bias is not set off by a commitment problem of the decision-making unit exhibiting the
} 
The paper proceeds as follows: Section 2 presents the model. Section 3 reviews the optimal corrective policy when the federal government has the ability to commit. Section 4 derives the optimal corrective grant rule applicable when a federal commitment to equalizing transfers is missing. Section 5 extends the model to include formula-based equalizing transfers and distortionary federal and local tax policy. A summary and some concluding remarks are offered in Section 6.

\section{The Model}

Private Sector Consider two states which may differ with respect to preferences and endowments. The representative household in state $i(i=1,2)$ derives utility from private and public consumption, $c^{i}$ and $G^{i}$, according to the well-behaved utility function $u^{i}(c, G) .{ }^{13}$ Public consumption in state $i$ depends on public funds spent in state $i, g^{i}$, and the neighboring state $j, g^{j}$ :

$$
G^{i}=g^{i}+\theta g^{j}, \quad j \neq i
$$

$\theta \in[0,1]$ measures the extent to which public expenditures of state $j$ spills over to state $i$. If $\theta=0$, public expenditures only affect the well-being of domestic households (local public good), whereas for $\theta=1$ they add to individual well-being irrespective of the household's place of residence (pure public good). For all intermediate cases, $\theta \in(0,1)$, state public expenditures can partially be consumed in the neighbor state (impure public goods).

Households have an endowment $I^{i}$ which is subject to local taxation. The private budget constraint is

$$
c^{i}=I^{i}-T^{i},
$$

where $T^{i}$ are taxes collected in state $i$.

Public Sector The public sector is modelled as a two-layer federal system. State governments finance public expenditures $\left\{g^{i}>0\right\}_{i=1,2}$ by locally collected taxes $\left\{T^{i}\right\}_{i=1,2}$ and equalizing transfers $\left\{s^{i}\right\}_{i=1,2}$ which are provided by the federal government. ${ }^{14}$ The federal transfer system is a net spending bias (state government), but rather is deduced from the federal government's temptation to adjust part of its decisions ex-post.

${ }^{13}$ To save on notation we omit the state-specific superscript when consumption levels are listed as arguments of individual well-being.

${ }^{14}$ Tax rates $\left\{T^{i}\right\}_{i=1,2}$ are not subject to non-negativity constraints in order to save on notation related to corner solutions (most notably in section 4). The main results of the paper are unaffected by the simplification. 
equalization scheme. Transfers to one state are financed by negative transfers to the other state. The federal and state budget constraints are thus

$$
s^{1}+s^{2}=0 \quad \text { and } \quad g^{i}=T^{i}+s^{i} .
$$

Both levels of government are assumed to be benevolent. State governments maximize utility of the representative household while the federal government chooses policy to maximize the Benthamite welfare function $\sum_{i=1,2} u^{i}(c, G) \cdot{ }^{15}$

Pareto-Efficiency The (first-best) efficient expenditure level in state $i$ is characterized by the modified Samuelson condition

$$
\frac{u_{G}^{i}}{u_{c}^{i}}+\theta \frac{u_{G}^{j}}{u_{c}^{j}}=1, \quad i \neq j
$$

The social marginal willingness to pay for additional public spending in state $i$ equals the social marginal rate of transformation normalized at unity.

\section{Review: Decentralized Public Policy with Federal Commitment}

To review the traditional implications for corrective policy, we first characterize the efficiency of decentralized public choices when the federal government is able to commit toward state governments with respect to transfer policy and, in a second step, devise the optimal corrective grant rule.

\subsection{Equilibrium Analysis}

A federal commitment capacity towards lower-level governments motivates the following sequence of decisions:

Stage 1: The federal level selects transfers $\left\{s^{i}\right\}_{i=1,2}$ anticipating states' policy choices.

Stage 2: States simultaneously select income taxes $\left\{T^{i}\right\}_{i=1,2}$ for given federal policy.

\footnotetext{
${ }^{15}$ Most of the simplifying assumptions are made for analytical and expositional convenience. For instance, the analysis can readily be extended to a finite number of states. Similarly, the basic results carry over to a state-specific spill-over parameter $\theta^{i}$. As will become clear in section 5, the set of federal policy instruments can also include formula-based equalization systems and distortionary taxes without quantitatively affecting the results of the paper. Also, in section 5 the equalization system is not required to be self-financing (net fiscal equalization) as it is in (3).
} 
Stage 3: Transfers $\left\{s^{i}\right\}_{i=1,2}$ are paid, taxes $\left\{T^{i}\right\}_{i=1,2}$ are collected, and households consume $\left\{c^{i}, G^{i}\right\}_{i=1,2}$.

We assume that state taxes are determined at stage 1; thereby capturing the idea that public expenditures can be adjusted in a more flexible fashion than the structure of the general tax system. ${ }^{16}$ Solving backwards, state government $i$ 's problem is to

$$
\max _{T^{i}} \quad u^{i}(c, G) \quad \text { s.t. Eqs. } \quad(1)-(3)
$$

taking $s^{i}, s^{j}$ and $T^{j}, i \neq j$, as given. The first-order condition is

$$
\frac{u_{G}^{i}}{u_{c}^{i}}=1
$$

Straightforwardly, if public expenditures do not spill-over $(\theta=0)$ decentralized policy is efficient, while it yields an under-provision equilibrium if spill-overs exist $(\theta \in(0,1])$.

Eq. (6) already suffices to devise the optimal corrective policy towards state governments. We thus omit a formal characterization of the federal transfer choice.

\subsection{Corrective Policy}

Consider a corrective grant $P^{i}\left(T^{i}\right)$ paid to state $i .{ }^{17}$ Policy instruments are decided upon in the following sequence:

Stage 0: The federal government announces the corrective grant system $\left\{P^{i}\left(T^{i}\right)\right\}_{i=1,2}$.

Stage 1: The federal level selects transfers $\left\{s^{i}\right\}_{i=1,2}$ anticipating states' policy choices.

Stage 2: States simultaneously select income taxes $\left\{T^{i}\right\}_{i=1,2}$ for given federal policy.

Stage 3: Transfers $\left\{s^{i}, P^{i}\left(T^{i}\right)\right\}_{i=1,2}$ are paid, taxes $\left\{T^{i}\right\}_{i=1,2}$ are collected, and households consume $\left\{c^{i}, G^{i}\right\}_{i=1,2}$.

\footnotetext{
${ }^{16}$ Although from a theoretical perspective the sequencing of state policies is ambiguous, anecdotal evidence suggests that it takes longer to pass through the legislative process associated with a significant change of the tax system. Decision on public expenditures, however, are numerously made in between.

${ }^{17} \mathrm{We}$ assume that the flat component of the grant absorbs the budgetary implications of corrective policy, such that $P^{i}\left(T^{i}\right)=0$ in equilibrium. Equally, the grant could be financed out of federal tax revenues provided the federal and local governments have the authority to levy distortionary taxes on not perfectly-overlapping tax bases (as demand for corrective policy would otherwise evaporate - see e.g. Boadway and Keen, 1996). Such a financing scheme would complicate the analysis considerably without altering the basic results - see subsection 5.2.
} 
Noting the augmented state budget constraint $G^{i}=T^{i}+s^{i}+P^{i}\left(T^{i}\right)$, the first-order condition in state $i$ becomes

$$
\frac{u_{G}^{i}}{u_{c}^{i}}\left(1+\frac{d P^{i}\left(T^{i}\right)}{d T^{i}}\right)=1
$$

Comparing (4) and (7), state government $i$ 's choice of taxes satisfies the Samuelson condition if the grant satisfies

$$
\frac{d P^{i}\left(T^{i}\right)}{d T^{i}}=\theta
$$

The grant rule (8) is reminiscent of the familiar prescription that, in a first-best environment, the corrective grant is equal to the marginal external effect ("Pigouvian taxation") - see e.g. Dahlby $(1996) .{ }^{18}$

\section{Decentralized Public Policy with Federal Non-Commitment}

If the federal government cannot commit to equalization policy, the sequence of decisions alters to:

Stage 1: States simultaneously select their taxes $\left\{T^{i}\right\}_{i=1,2}$ taking the reaction of the federal government into account.

Stage 2: The federal level chooses transfers $\left\{s^{i}\right\}_{i=1,2}$ for given states' policy choices $\left\{T^{i}\right\}_{i=1,2}$.

Stage 3: Transfers $\left\{s^{i}\right\}_{i=1,2}$ are paid, taxes $\left\{T^{i}\right\}_{i=1,2}$ are collected, and households consume $\left\{c^{i}, G^{i}\right\}_{i=1,2}$.

The game is solved backwards to identify a subgame-perfect Nash-equilibrium. In the subsequent analysis we first restrict attention to $\theta \in[0,1)$ and relegate the case of $\theta=1$ to subsection 4.2 .

\footnotetext{
${ }^{18}$ Note, albeit the marginal externality $\frac{1}{u_{c}^{j}} \frac{d u^{j}}{d T^{i}}=\theta \frac{u_{G}^{j}}{u_{c}^{j}}, i \neq j$, differs across states, the required grant rule is the same for everyone. Following (7) and (8) the marginal rates of substitution between private and public consumption are aligned. State $i$ 's marginal evaluation of the corrective grant thereby coincides with the marginal externality.
} 


\subsection{Impure Public Consumption $(\theta \in[0,1))$}

\subsubsection{Equilibrium Analysis}

Federal Government At stage 2, the federal government solves

$$
\max _{\left\{s^{i}\right\}_{i=1,2}} \sum_{i=1,2} u^{i}(c, G) \quad \text { s.t. } \quad \text { Eqs. (1) - (3), }
$$

taking states' policy choices $\left\{T^{i}\right\}_{i=1,2}$ as given. If $\theta \in[0,1)$, the first-order condition is ${ }^{19}$

$$
u_{G}^{i}=u_{G}^{j}, \quad i \neq j
$$

The federal government makes transfers so as to equalize the marginal utility of public consumption nationwide. The federal first-order condition (10) together with the federal budget constraint $s^{1}+s^{2}=0$ implicitly define the best-response $s^{i}=\varphi^{i}\left(T^{i}, T^{j}\right)$. Differentiating the federal firstorder condition and the federal budget constraint with respect to $s^{i}, s^{j}$, and $T^{i}$ and inserting $-\frac{\partial}{\partial T^{i}} s^{i}=\frac{\partial}{\partial T^{i}} s^{j}$ in the differentiated first-order condition, to eliminate the $s^{j}$ derivative, gives

$$
\frac{\partial s^{i}}{\partial T^{i}}=\frac{u_{G c}^{i}-u_{G G}^{i}+\theta u_{G G}^{j}}{\Delta}, \quad i \neq j
$$

with $\Delta:=(1-\theta)\left(u_{G G}^{i}+u_{G G}^{j}\right)<0$.

State Government State government $i$ solves

$$
\max _{T^{i}} \quad u^{i}(c, G) \quad \text { s.t. } \quad s^{i}=\varphi^{i}\left(T^{i}, T^{j}\right) \quad \text { and } \text { Eqs. (1) - (3). }
$$

Using $\frac{\partial}{\partial T^{i}} s^{j}=-\frac{\partial}{\partial T^{i}} s^{i}$ the first-order condition is ${ }^{20}$

$$
\frac{u_{G}^{i}}{u_{c}^{i}}\left(1+(1-\theta) \frac{\partial s^{i}}{\partial T^{i}}\right)=1, \quad i \neq j .
$$

Reflected by the term $(1-\theta) \frac{\partial s^{i}}{\partial T^{i}}$, ex-post redistribution alters the tax price of marginal state spending. At the root of it, transfers are lump-sum from an ex-post perspective, but are ex-ante

\footnotetext{
${ }^{19}$ Differentiating the Benthamite welfare function subject to the constraints yields $u_{G}^{i}+\theta u_{G}^{j}=u_{G}^{j}+\theta u_{G}^{i}, i \neq j$, which after rearranging reduces to condition (10).

${ }^{20}$ Equilibrium existence follows from standard fixed-point arguments. Compared with the game analyzed in the previous section, the class of preferences for which an equilibrium exists is more restricted. The restriction comes from ex-post federal transfer policy characterized by the first-order condition (10) and the induced federal response (11). If states are asymmetric, the federal response is generically non-uniform across states. Following the state first-order condition (13) an equilibrium can only exist if preferences allow the marginal utility of private consumption to differ across states. With asymmetric states the condition in general rules out preferences which are quasi-linear in private consumption.
} 
perceived to be conditional on state policy. To illustrate the tax price effect on state tax policy, consider $u_{G c}^{i} \equiv 0$ in which case two countervailing incentive effects are embodied in ex-post transfer policy. First, the federal concern for ex-post equity establishes a revenue-sharing system. More locally collected tax revenues $T^{i}$ reduce the amount of transfers, which undermines state $i$ 's taxing incentives. The disincentive effect is captured by $u_{G G}^{i}$ in the numerator of (11). Second, when $\theta \in(0,1)$ ex-post transfers exhibit a Pigouvian effect which is captured by $\theta u_{G G}^{j}$ in (11). As the federal government equalizes the marginal utility of public consumption at the second stage, state government $i$ 's policy choice reflects the consumption spill-over to the extent to which the spillover determines the adjustment in equalizing transfers. The overall sign of the transfer response is ambiguous. If $u_{G G}^{i}>(<) \theta u_{G G}^{j}$, the concern for ex-post equity strengthens (weakens) state $i$ 's incentive to contribute to the public good.

Given the federal budget constraint (3), state $i$ 's tax choice has a bearing on state $j$ 's public consumption. When $\theta>0$, state $i$ sees through state $j$ 's budget and a fraction $\theta$ of the cross-budget effect is internal to state $i$ 's policy choice. As $\frac{\partial}{\partial T^{i}} s^{i}=-\frac{\partial}{\partial T^{i}} s^{j}$, only $1-\theta$ of the change in ex-post transfers $\frac{\partial}{\partial T^{i}} s^{i}$ enters the first-order condition (13).

The state policy choice (13) differs from the socially optimal choice (4). ${ }^{21}$ The wedge between the social and private effect of a tax rise in state $i$ is

$$
\frac{1}{u_{c}^{j}} \frac{d u^{j}(c, G)}{d T^{i}}=\frac{u_{G}^{j}}{u_{c}^{j}}\left(\theta+(1-\theta) \frac{\partial s^{j}}{\partial T^{i}}\right), \quad i \neq j .
$$

First, state $i$ 's tax policy yields a consumption spill-over at magnitude $\theta$. Second, through the induced policy response of the federal government, state $i$ 's tax rate choice influences welfare in state $j$ as captured by $(1-\theta) \frac{\partial}{\partial T^{2}} s^{j}$.

The following two examples illustrate the decentralized equilibrium:

Example 1: Consider the preferences to be $u^{i}(c, G)=\ln c^{i}+\ln G^{i}$ and $u^{j}(c, G)=\ln c^{j}+$

\footnotetext{
${ }^{21}$ Both rules may incidentally coincide. The possibility is captured by the subsequent analysis, but to ease the exposition it is not explicitly referred to.
} 
$\alpha \ln G^{j}, \alpha>0$. The equilibrium transfer response is

$$
\frac{\partial s^{i}}{\partial T^{i}}=\frac{\theta-\alpha}{(1-\theta)(1+\alpha)}<0
$$

The non-negativity constraints on $\left\{g^{i}\right\}_{i=1,2}$ imply that $\alpha$ and $\theta$ must satisfy $\theta<\alpha$ if $\alpha \leq 1$ and $\theta<\alpha^{-1}$ if $\alpha>1$. The conditions sign $\frac{\partial}{\partial T^{i}} s^{i}$ negative which reveals that the revenue-sharing effect dominates the Pigouvian effect of ex-post transfer policy.

The marginal externality on state $j$ 's public consumption is

$$
\theta+(1-\theta) \frac{\partial s^{j}}{\partial T^{i}}=\theta+\frac{\alpha-\theta}{1+\alpha}>0, \quad i \neq j .
$$

It is positive as the spill-over and, following (3) and (15), the transfer-induced externality are of the same sign. The equilibrium thus exhibits an under-consumption of public goods.

Example 2: Alternatively consider $u^{i}(c, G)=\ln c^{i}+G^{i}$ and $u^{j}(c, G)=\ln c^{j}+\alpha \ln G^{j}, \alpha>0$. State $i$ 's transfer response (11) reduces to $\frac{\partial}{\partial T^{i}} s^{i}=\frac{\theta}{1-\theta}$ and, following (3), the externality on state $j$ is

$$
\theta+(1-\theta) \frac{\partial s^{j}}{\partial T^{i}}=0, \quad i \neq j
$$

Note, the federal first-order condition (10) is $G^{j}=\alpha$. When $\theta=0$, federal transfers do not respond to state $i$ 's tax policy as $G^{j}$ is independent of $T^{i}$ - see (1) and (3). When $\theta \in(0,1)$, the transfer response is contrary to the spill-over on state $j$ 's public consumption (so as to keep $G^{j}$ constant); entailing an efficient policy choice in state $i$.

The identified equilibria are contrary to the over-provision equilibria familiar from models of soft-budget constraints; predominantly resorting to a two-period setting (Kornai et al., 2003). The current static setting coequally exhibits a tendency for state governments to over-provide the public good, provided state policy choices are made in a different order. If public expenditures rather than taxes are chosen at stage 1 , and taxes adjust residually at stage 3 , the revenue-sharing effect turns into a cost-sharing effect; yielding a over-provision equilibrium most notably when private and public consumption are weak complements $\left(u_{c G} \geq 0\right)$ - see Akai and Sato (2005). They consider either additively separable preferences or the absence of spill-overs - two "limit" versions 
of the current model. As shown in the appendix, over-provision extends as the unique equilibrium prediction to the general model provided $u_{c G} \geq 0$.

In the sequel we adhere to the view that state governments optimize over taxes and expenditures adjust residually.

\subsubsection{Corrective Policy}

Denoting $P^{i}\left(T^{i}\right)$ as the corrective grant to state $i$, which in contrast to equalizing transfers is ex-ante conditioned on state $i$ 's tax rate, public consumption reads:

$$
G^{i}=T^{i}+s^{i}+P^{i}\left(T^{i}\right)+\theta\left(T^{j}+s^{j}+P^{j}\left(T^{j}\right)\right), \quad i \neq j .
$$

The overall transfer scheme $\left\{s^{i}, P^{i}\left(T^{i}\right)\right\}_{i=1,2}$ serves a dual role: equalizing transfers $\left\{s^{i}\right\}_{i=1,2}$ expost redistribute public wealth between states, while the grant $P^{i}\left(T^{i}\right)$ establishes efficiency of state government policy.

The extended sequence of decisions is:

Stage 0: The federal government announces the corrective grant system $\left\{P^{i}\left(T^{i}\right)\right\}_{i=1,2}$.

Stage 1: States simultaneously select their tax rates $\left\{T^{i}\right\}_{i=1,2}$ subject to $\left\{P^{i}\left(T^{i}\right)\right\}_{i=1,2}$ and the federal government's choice of equalizing transfers.

Stage 2: The federal level decides upon the level of equalizing transfers $\left\{s^{i}\right\}_{i=1,2}$ for given states' policy choices.

Stage 3: Transfers $\left\{s^{i}, P^{i}\left(T^{i}\right)\right\}_{i=1,2}$ are paid, taxes $\left\{T^{i}\right\}_{i=1,2}$ are collected, and households consume $\left\{c^{i}, G^{i}\right\}_{i=1,2}$.

The sequence of federal policy is motivated by the notion of a "social citizenship" which stipulates a "equitable" ex-post distribution of public consumption across states. Given the set of policy instruments $\left\{s^{i}, P^{i}\left(T^{i}\right)\right\}_{i=1,2}$, the principle will in the first place induce an ex-post adjustment of transfer policy $\left\{s^{i}\right\}_{i=1,2}$ (being more effective in addressing distributional concerns). Thus, the prerogative is less likely to undermine the federal government's ability to commit to corrective policy.

The game is solved by backward induction. At stage 2 the federal government sets equalizing 
transfers, $\left\{s^{i}\right\}_{i=1,2}$, so as to equate the marginal benefit of public consumption. (10) and (18) define the ex-post transfer policy $\left\{s^{i}=\Phi^{i}\left(T^{i}, T^{j}\right)\right\}_{i=1,2}$. Applying the equivalent steps as in deriving Eq. (11), we get

$$
\frac{\partial s^{i}}{\partial T^{i}}=\left.\frac{\partial s^{i}}{\partial T^{i}}\right|_{d P^{i}\left(T^{i}\right)=0}-\frac{u_{G G}^{i}-\theta u_{G G}^{j}}{\Delta} \frac{d P^{i}\left(T^{i}\right)}{d T^{i}}, \quad i \neq j,
$$

with $\Delta:=(1-\theta)\left(u_{G G}^{i}+u_{G G}^{j}\right)<0$. The first term on the right-hand side of (19) gives the change in equalizing transfers keeping the corrective grant constant - see (11). The corrective grant intertwines with ex-post transfer policy. To the extent that the corrective grant has a bearing on state $i$ 's public consumption, the amount of equalizing transfers will adjust so as to re-establish $u_{G}^{i}=u_{G}^{j}$. The effect is measured by the second term on the right-hand side of (19). With asymmetric preferences we may observe sufficiently different curvature properties of preferences which leaves $\omega^{i}:=\frac{u_{G G}^{i}-\theta u_{G G}^{j}}{\Delta}$ ambiguous in sign.

At stage 1 , state $i$ 's problem is to

$$
\max _{T^{i}} \quad u^{i}(c, G) \quad \text { s.t. } \quad s^{i}=\Phi^{i}\left(T^{i}, T^{j}\right), P^{i}\left(T^{i}\right) \quad \text { and } \quad \text { Eqs. (1) - (3). }
$$

For $\theta \in[0,1)$, the first-order condition is

$$
-u_{c}^{i}+u_{G}^{i}\left(1+\frac{\partial s^{i}}{\partial T^{i}}+\frac{d P^{i}\left(T^{i}\right)}{d T^{i}}+\theta \frac{\partial s^{j}}{\partial T^{i}}\right)=0, \quad i \neq j .
$$

Besides the direct effect of corrective policy, $\frac{d}{d T^{i}} P^{i}\left(T^{i}\right)$ enters (20) through the adjustment in equalizing transfers at a rate of $-\omega^{i}$ (through $\left.\frac{\partial}{\partial T^{i}} s^{i}\right)$ and $\theta \omega^{i}\left(\operatorname{through} \theta \frac{\partial}{\partial T^{i}} s^{j}\right)$. The direct and indirect effects combine such that only $1-(1-\theta) \omega^{i}>0$ per unit of the marginal corrective grant influences state $i$ 's tax policy.

Requiring that state $i$ 's policy choice satisfies the Samuelson condition (4) gives:

Proposition 1: Let $\theta \in[0,1)$. State $i$ 's tax policy is (first-best) efficient if the corrective grant, $P^{i}\left(T^{i}\right)$, satisfies

$$
\frac{d P^{i}\left(T^{i}\right)}{d T^{i}}=\left(\theta+\left.(1-\theta) \frac{\partial s^{j}}{\partial T^{i}}\right|_{d P^{i}\left(T^{i}\right)=0}\right)\left(1-(1-\theta) \omega^{i}\right)^{-1}, \quad i \neq j .
$$


The first bracketed term includes the two types of externalities state $i$ exerts on the well-being of state $j$ 's residents - the consumption spill-over and the transfer adjustment (see Eq. (14)). The second term accounts for the adjustment of ex-post transfer policy. The inherent tax price bias implicates that $1-(1-\theta) \omega^{i}>0$ rather than 1 per unit of the marginal corrective grant influences state $i$ 's spending choice. The federal government induces the state government to correctly evaluate the externality at the social price of public spending $(=1)$ when providing a subsidy $\left(1-(1-\theta) \omega^{i}\right)^{-1}>0$ per unit of the marginal externality.

To show the implications of ex-post redistribution most clearly, consider consumption spill-overs to be absent $(\theta=0)$. In this case, the externality term in $(21)$ only comprises $\left.\frac{\partial s^{j}}{\partial T^{i}}\right|_{d P^{i}\left(T^{i}\right)}$, while the subsidy becomes $1-\omega^{i}>0$. Ex-post redistribution in itself necessitates a corrective policy; whether it entails a tax or subsidy on state taxing effort depends on the sign of the transfer-induced externality.

Two observations are noteworthy. First, the grant rule (21) is independent of state $j$ 's marginal rate of substitution between private and public consumption at which it evaluates the consumption spill-over and the adjustment in transfers. Implementing the grant rule (21) equalizes the marginal rates of substitution across states. State $i$ 's equilibrium evaluation of the corrective grant is thereby aligned to the equilibrium externality (14). Second, albeit taxes are lump-sum, the corrective grant is in general not strictly Pigouvian unless the subsidy $\left(1-(1-\theta) \omega^{i}\right)^{-1}=1$. To illustrate the observation we re-consider log-linear preferences as in example 1.

Example 1 (cont'd.): The subsidy term in (21) becomes

$$
\left(1-(1-\theta) \omega^{i}\right)^{-1}=\frac{(1-\theta)(1+\alpha)}{(1-\theta \alpha)(1+\theta)}>0 .
$$

By the non-negativity of $\left\{c^{i}, g^{i}\right\}_{i=1,2}, \alpha$ and $\theta$ must satisfy $\theta<\alpha$ if $\alpha \leq 1$ and $\theta<\alpha^{-1}$ if $\alpha>1$ which renders the term (22) positive. Depending on whether the subsidy exceeds or falls below the marginal cost of public funds, the externality is over- or under-represented in the grant rule as illustrated in figure 1. All $(\alpha, \theta)$ combinations below the first linearly upward- and beyond $\alpha>1$ downward-sloping curve satisfy the non-negativity constraints on $\left\{c^{i}, g^{i}\right\}_{i=1,2}$. The 


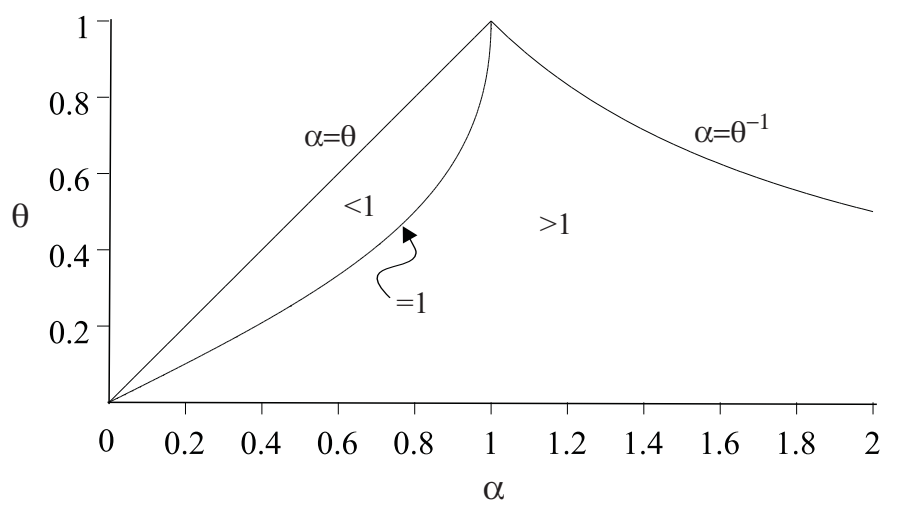

Figure 1: $\left(1-(1-\theta) \omega^{i}\right)^{-1}$ for additively separable, logarithmic preferences.

convex, upward-sloping curve depicts the parameter combinations for which the grant rule equiproportionally represents the equilibrium externality, with combinations above (below) the line yielding under- (over-) representation. Intuitively, ex-post transfers may impair or ameliorate state $i$ 's fiscal ability to spend out of grant income. When the social value of state spending is sufficiently high (as captured by $\theta$ ), the transfer system may provide a premium per unit of the marginal grant $\left(1-(1-\theta) \omega^{i}>1\right)$. As a corrective measure, the optimal subsidy falls below unity. The equalizing transfer system implicitly imposes a tax on received corrective grants $\left(1-(1-\theta) \omega^{i}<1\right)$ whenever public consumption is strongly valued by the neighbor state (as captured by $\alpha$ ). The required subsidy is one which exceeds unity.

\subsection{Pure public consumption $(\theta=1)$}

In this subsection we ask how corrective policies need to be designed when $\theta=1$ - a property throughout assumed in public good contribution games (e.g. Boadway et al., 1989). In this environment the states' contribution levels $\left\{g^{i}\right\}_{i=1,2}$ are perfect substitutes in public consumption which, since $\frac{\partial}{\partial T^{i}} s^{i}+\frac{\partial}{\partial T^{i}} s^{j}=0$, leaves state $i$ 's public consumption independent of how equalizing transfers are allocated ex-post. Ex-post transfer policy has no bearing on the tax price of marginal state expenditures and, consequently, state $i$ chooses an inefficiently low level of taxation only reflecting incentives to free-ride on state $j$ 's contribution - a disincentive which can be corrected by selecting the grant rule (8). Thus, 
Proposition 2: If $\theta=1$, the appropriate corrective grant rule is independent of the federal government's ability to commit to transfer policy. Efficiency obtains when the marginal corrective grant satisfies (8) evaluated at $\theta=1$.

A straightforward question relates to the generality of the equivalence result. Caplan et al. (2000) and Chiappori and Werning (2002) show that it does not extend to all pure public good provision games augmented by ex-post transfer policy. Concretely, it is sensitive to what the redistributive scheme primarily targets. When the federal government is concerned about the ex-post interregional distribution of private consumption, corrective policy may not be needed, most notably in environments with symmetric preferences. The conclusion also applies when transfers enter the public budget (as assumed in the current paper), but state governments optimize over expenditures and taxes adjust residually. The federal government effectively aligns private consumption possibilities (Akai and Sato, 2005) ${ }^{22}$; establishing the incentive effects in state policy delineated in Caplan et al. and Chiappori and Werning. By contrast, drawing on the analysis in subsection 3.1, there is universal (i.e. for (a)symmetric preferences) demand for corrective policy in the presence of federal commitment to transfer policy. ${ }^{23}$

\section{Extensions}

So far, we resorted to a simple economy, just rich enough to identify the source of deviation from the Pigouvian rule. In this section we explore the robustness of our results by incorporating formulabased equalization schemes and federal taxing powers, respectively. We retain the assumptions of the baseline model unless explicitly stated. In all extensions we are only concerned with corrective policies required when transfers are set ex-post.

\subsection{Formula-Based Equalizing Transfers}

Consider state $i$ receives a formula-based transfer

$$
z^{i}=\alpha\left(T^{j}-T^{i}\right), \quad \alpha \in[0,1), \quad i \neq j,
$$

\footnotetext{
${ }^{22}$ To see the conclusion more firmly, note that for the sequence of events depicted in the appendix the first-order condition (27) also applies when $\theta=1$.

${ }^{23}$ Straightforwardly, the first-order condition (6) robustly predicts optimal state policy in games with a federal pre-commitment capacity; i.e. it holds irrespective of whether $(i)$ transfers are paid to the private or public budget, and $(i i)$ state governments optimize over taxes or expenditures.
} 
with $z^{1}+z^{2}=0$. The scheme allocates funds to the state which falls behind in terms of own source state revenues. ${ }^{24}$ The sequence of decisions, augmented by formula-based equalization policy, is:

Stage 0: The federal government announces the formulaic equalization system $\left\{z^{i}\right\}_{i=1,2}$.

Stage 1: State governments simultaneously select their income taxes $\left\{T^{i}\right\}_{i=1,2}$ taking the tax policy of other governments as given.

Stage 2: The federal level chooses transfers $\left\{s^{i}\right\}_{i=1,2}$ for given states' policy choices $\left\{T^{i}\right\}_{i=1,2}$.

Stage 3: Transfers $\left\{s^{i}, z^{i}\right\}_{i=1,2}$ are paid, taxes $\left\{T^{i}\right\}_{i=1,2}$ are collected, and households consume $\left\{c^{i}, G^{i}\right\}_{i=1,2}$.

When $\theta \in[0,1)$, the marginal adjustment in $s^{i}$ following a rise in $T^{i}$ is $^{25}$

$$
\frac{\partial s^{i}}{\partial T^{i}}=\left.\frac{\partial s^{i}}{\partial T^{i}}\right|_{\alpha=0}+\alpha, \quad \alpha \in[0,1)
$$

In addition to the transfer adjustment derived in the last section, $s^{i}$ is increased at an amount equal to the marginal downward adjustment in $z^{i}$ as captured by $\alpha$ in (24). The ex-post adjustment renders the formula-based transfer scheme neutral for state policy choices. The equilibrium inefficiency continues to be characterized by (14), and the appropriate corrective grant rule is prescribed by $(21)$.

When $\theta=1$, the interstate distribution of both lump-sum and formulaic transfers is neutral for public good consumption. State tax policy is identical to the policy chosen when the federal government can commit to transfer policy. The required corrective grant rule is (8). ${ }^{26}$

\footnotetext{
${ }^{24}$ The argument does not depend on the formula specified in (23). It extends to any budget-balancing (non-linear) equalization scheme.

${ }^{25}$ The federal choice of lump-sum transfers satisfies first-order condition (10) with (1) and $g^{i}=T^{i}+z^{i}+s^{i}$ determining public consumption. Following the same steps as in deriving (19) gives the slope of the ex-post transfer function (24).

${ }^{26}$ More generally, when the federal government is able to commit to transfer policy, the externality comprises the consumption spill-over $\theta$ and the marginal effect of state $i$ 's taxing effort on transfer entitlement (and thus public consumption) of the neighbor state, $\frac{\partial}{\partial T^{i}} z^{j}=\alpha$. As a fraction $\theta$ of the transfer entitlement spills back to state $i$, the grant rule reads $\frac{d}{d T^{i}} P^{i}\left(T^{i}\right)=\theta+(1-\theta) \alpha$ which reduces to (8) for $\theta=1$.
} 


\subsection{Federal Tax Policy}

Thus far, the federal government only selects the ex-post horizontal allocation of state public spending. In this subsection we adopt the more comprehensive view that the federal government can also influence the allocation of resources by (distortionary) taxation and public spending. In doing so, we extend the model in various ways. We allow households to make economic decisions (e.g. related to physical consumption and leisure). The induced indirect utility function is of the form $v^{i}\left(t^{i}, T^{i}\right)+h^{i}\left(G^{i}\right)+v^{i}(F)$, where $t^{i}$ is the federal tax rate levied on households in state $i$ and $F$ is a pure pubic good which is provided by the federal government. ${ }^{27}$ State and federal tax revenues collected in state $i$ are $r^{i}\left(T^{i}, t^{i}\right)$ and $R^{i}\left(T^{i}, t^{i}\right)$, respectively. We assume that taxes are distortionary and that the tax bases assigned to both layers of government do not perfectly overlap. ${ }^{28}$ The reason why we elude a perfect tax base overlap is that in such a setting, demand for corrective policy evaporates (e.g. Boadway and Keen, 1996, and Akai and Sato, 2005). When $r^{i}\left(t^{i}+T^{i}\right)$ and $R^{i}\left(t^{i}+T^{i}\right)$, the federal government can initiate a federal tax policy and a intergovernmental distribution of tax revenues (via $\left\{s^{i}\right\}_{i=1,2}$ ), which implements the (second-best) efficient allocation. The federal budget constraint is

$$
\sum_{i=1,2} P^{i}\left(T^{i}\right)+\sum_{i=1,2} s^{i}+F=\sum_{i=1,2} R^{i}\left(T^{i}, t^{i}\right)
$$

Contrary to the baseline model, we now allow for the possibility that equalizing transfers are financed by federal taxes (gross equalization scheme). Incorporating corrective grants, federal and state policy decisions are:

Stage 0: The federal government announces the corrective grant scheme $\left\{P^{i}\left(T^{i}\right)\right\}_{i=1,2}$.

Stage 1: The federal government and states simultaneously select their taxes $\left\{t^{i}, T^{i}\right\}_{i=1,2}$ taking the tax policy of other governments as given.

Stage 2: The federal level chooses transfers $\left\{s^{i}\right\}_{i=1,2}$ for given states' policy choices $\left\{T^{i}\right\}_{i=1,2}$.

\footnotetext{
${ }^{27}$ The separability of preferences between private and public consumption is adopted for the ease of exposition. A non-additive structure would allow public consumption to enter the tax base of each layer of government. The grant formula would include additional terms reflecting this interaction, but its qualitative structure would be unaffected.

${ }^{28} \mathrm{~A}$ variety of structural models may underly the reduced-form specification. For instance, direct utility may be defined over leisure and at least two consumption goods. The federal government may tax a subset of the consumption goods at the rate $t^{i}$, while state governments tax a subset of commodities, which does not perfectly overlap with the federal tax base, at a rate $T^{i}$.
} 
Stage 3: Transfers $\left\{s^{i}, P^{i}\left(T^{i}\right)\right\}_{i=1,2}$ are paid, tax revenues $\left\{r^{i}\left(T^{i}, t^{i}\right), R^{i}\left(T^{i}, t^{i}\right)\right\}_{i=1,2}$ are collected, and households consume $\left\{c^{i}, G^{i}, F\right\}_{i=1,2}$.

As in section 4, we take the view that the notion of a "social citizenship" undermines the federal government's ability to commit to equalizing transfers. We assume that the federal tax system is determined at stage 1 ; thereby capturing the idea that transfers can be adjusted ex-post in a more flexible fashion than the structure of the general tax system.

We subsequently characterize federal policy choices to the extent to which they are informative for corrective grant design. We thus omit a formal analysis of the federal policy choices $\left\{T^{i}\right\}_{i=1,2}$ and $F$.

\subsubsection{Impure Public Consumption $(\theta \in[0,1))$}

As before, equalizing transfers satisfying $h_{G}^{i}=h_{G}^{j}$ are a Nash-equilibrium of the stage 2 sub-game. Reiterating the steps as in deriving (19) we get $^{29}$

$$
\frac{\partial s^{i}}{\partial T^{i}}=\left.\frac{\partial s^{i}}{\partial T^{i}}\right|_{d P^{i}\left(T^{i}\right)=0}-\frac{h_{G G}^{i}-\theta h_{G G}^{j}}{\Delta} \frac{d P^{i}\left(T^{i}\right)}{d T^{i}}, \quad i \neq j,
$$

with $\Delta:=(1-\theta)\left(h_{G G}^{i}+h_{G G}^{j}\right)<0$. The tax price bias inherent in ex-post transfer policy impairs the incentive effect of the grant. As stipulated in Proposition 1, the corrective grant must account for the tax price bias in addition to the externality. The grant rule however deviates in two respects from the rule in Proposition 1. First, distortionary taxation induces that the externality will be "under-corrected" (Sandmo, 1975, and Bovenberg and van der Ploeg, 1994). Denoting $\lambda$ as the marginal utility of private income, and $\mu$ as the marginal disutility of raising public funds, the corrective part of the subsidy is weighted by the inverse of the marginal cost of public funds $\frac{\mu}{\lambda}>1 .^{30}$ The required under-correction of the externality may be accomplished by a subsidy exceeding the inverse of the marginal cost of public funds and possibly, exceeding unity. Second, the grant has to correct a vertical fiscal externality. To the extent that state taxation affects federal tax revenues $\left(R_{T^{i}} \neq 0\right)$, the level of the pure public good $F$ consumed by the residents of the neighboring state

\footnotetext{
${ }^{29}$ The first term on the right-hand side is qualitatively similar to (11) (now omitting the interaction between private and public consumption in preferences).

${ }^{30}$ We consider the realistic scenario of $\frac{\mu}{\lambda}>1$. See Auerbach and Hines (2002) for a discussion.
} 
will adjust. $^{31}$

\subsubsection{Pure Public Consumption $(\theta=1)$}

Again, with pure public good, the inefficiency in local policy choices is independent of the federal government's concern for ex-post equity. ${ }^{32}$ To realize a second-best efficient allocation, the optimal grant rule needs to reflect the consumption spill-over and the vertical fiscal externality stemming from a change in pure public good provision when $R_{T^{i}} \neq 0$. Both externalities will be undercorrected due to reliance on distortionary tax financing (Sandmo, 1975, and Bovenberg and van der Ploeg, 1994).

\section{Conclusion}

The paper analyzes the design of corrective grants if the federal government is constrained in its ability to pre-commit. Such a constraint may follow from the notion of a "social citizenship" which gives a central preference for an ex-post equitable distribution of public service across states.

Several conclusions have emerged from the analysis. First, ex-post transfer policy induces a tax price effect in state policy which - a priori - may undermine or enhance efficiency. The inefficiency in lower-level public finance differ in nature and magnitude from the inefficiency with a federal commitment to transfer policy. Second, the implication for corrective grants relate not only to the type of externality to be addressed by the grant. It also bears on whether the grant rule is strictly Pigouvian, i.e. equi-proportional to the marginal externality. Even when lump-sum taxes are available, the grant rule is generically disproportionate to the external effect. The rationale is that the grant also corrects the tax price bias - an effect which emerges independently of the mode of financing. Third, when public consumption is pure, ex-post redistribution leaves lower-level government incentives unaffected and the existing prescription for corrective federal policy applies.

The analysis abstracts from dynamic aspects. The ratchet effect under scrutiny in the paper is frequently elaborated in a two-period setting where policy commitment only relates to the first

\footnotetext{
${ }^{31}$ In principle, the federal government could sidestep the bottom-up vertical fiscal externality by setting $t^{i}=0$ (e.g. Boadway and Keen, 1996, and Boadway and Tremblay, 2005). However, when the tax bases are not perfectly overlapping, the set of optimal taxes generally involves a positive $t^{i}$.

${ }^{32}$ Note, the neutrality result is to be distinguished from Warr neutrality (Warr, 1983). The latter presupposes at the very least that tax authority is perfectly overlapping (Bernheim, 1986).
} 
period and policy is "ratcheted" in the second period based on first-period observables. ${ }^{33}$ Consider a two period model in which the first period is the same as in section 3 (commitment) and the second period policy is as in section 4 in the (non-commitment). In such an economy the optimal dynamic corrective policy is a sequence of grants satisfying (8) in the first period and (21) in the preceding period. We should note that the paper does not lose relevance when public debt financing links pubic expenditure programmes intertemporally. The local public spending pattern becomes more skewed toward first-period consumption (Goodspeed, 2002), but equally exhibits a bias in the tax price of marginal state spending and yields the type of externalities characterized in the paper. ${ }^{34}$ The corrective policy now needs to address multiple efficiency margins; public consumption levels and the financing mix. The corrective grant will thus not be formally prescribed by the formula derived in the paper; however the insight that the subsidy on the externality will not only reflect the inverse of the social marginal cost of public funds will suggestively resurge when devising the optimal dynamic grant structure.

Finally, the paper adopts the view that the structure of the general tax system is pre-determined vis-a-vis state policy. Another extension would include a federal tax policy which is set ex-post along with equalization transfers (as in Akai and Sato, 2005). We leave such an exercise to future research.

\section{A Appendix: Alternative sequencing of state policy}

Consider a impure public good contribution game $(\theta \in[0,1))$ as depicted in subsection 4.1 ; however with the following alternative sequence of decisions:

Stage 1: States simultaneously select $\left\{g^{i}\right\}_{i=1,2}$ taking the reaction of the federal government into account.

Stage 2: The federal level chooses transfers $\left\{s^{i}\right\}_{i=1,2}$ for given states' policy choices $\left\{g^{i}\right\}_{i=1,2}$.

Stage 3: Transfers $\left\{s^{i}\right\}_{i=1,2}$ are paid, taxes $\left\{T^{i}\right\}_{i=1,2}$ are collected, and households consume $\left\{c^{i}, G^{i}\right\}_{i=1,2}$.

\footnotetext{
${ }^{33}$ See e.g. Freixas et al. (1985) and Dillen and Lundholm (1996).

${ }^{34}$ The source of inefficiency may widen. It is augmented by a pecuniary externality provided states do not act as price-takers in the international capital market.
} 
At stage 2, the federal government solves

$$
\max _{\left\{s^{i}\right\}_{i=1,2}} \sum_{i=1,2} u^{i}(c, G) \text { s.t. Eqs. (1) - (3), }
$$

Noting that $c^{i}=I^{i}-g^{i}+s^{i}$, the first-order condition

$$
u_{c}^{i}=u_{c}^{j}, \quad i \neq j
$$

defines ex-post transfers as a function of each state's contribution level, $s^{i}=\varphi^{i}\left(g^{i}, g^{j}\right)$. Differentiating the federal first-order condition with respect to $s^{i}, s^{j}$, and $g^{i}$ and inserting $-\frac{\partial}{\partial g^{i}} s^{i}=\frac{\partial}{\partial g^{i}} s^{j}$ gives

$$
\frac{\partial s^{i}}{\partial g^{i}}=\frac{u_{c c}^{i}-u_{c G}^{i}+\theta u_{c G}^{j}}{\Gamma}, \quad i \neq j
$$

with $\Gamma:=u_{c c}^{i}+u_{c c}^{j}<0$.

At stage 1 , state government $i$ solves

$$
\max _{g^{i}} \quad u^{i}(c, G) \quad \text { s.t. } \quad s^{i}=\varphi^{i}\left(g^{i}, g^{j}\right) \text { and Eqs. (1) - (3). }
$$

Using $\frac{\partial}{\partial g^{i}} s^{j}=-\frac{\partial}{\partial g^{i}} s^{i}$ the first-order condition is

$$
\frac{u_{G}^{i}}{u_{c}^{i}}=1-\frac{\partial s^{i}}{\partial g^{i}}
$$

Adding up the first-order conditions of state $i$ and $j$ yields

$$
\frac{u_{G}^{i}}{u_{c}^{i}}+\frac{u_{G}^{j}}{u_{c}^{j}}=2-\left(\frac{\partial s^{i}}{\partial g^{i}}+\frac{\partial s^{j}}{\partial g^{j}}\right), \quad i \neq j
$$

It follows from (28) that

$$
\frac{\partial s^{i}}{\partial g^{i}}+\frac{\partial s^{j}}{\partial g^{j}}=1-\frac{(1-\theta)\left(u_{c G}^{i}+u_{c G}^{j}\right)}{\Gamma}, \quad i \neq j .
$$

Assume private and public consumption to be weak complements, i.e. $u_{c G} \geq 0$. In this case (31) reveals $\frac{\partial}{\partial g^{i}} s^{i}+\frac{\partial}{\partial g^{j}} s^{j} \geq 1$ and (30) predicts that in any equilibrium the sum on the left-hand-side is $\leq 1$. As a final step, comparing (30) with the Samuelson condition (4) gives the result that public consumption will unambiguously be over-provided if $u_{c G} \geq 0$. 


\section{References}

[1] A. Auerbach and J. Hines, Taxation and economic efficiency, in: A. Auerbach and M. Feldstein (eds.), Handbook of Public Economics, vol 3 (2002) 1347 - 1421.

[2] N. Akai and T. Ihori, Central government subsidies to local public goods, Economics of Governance 3 (2002) 227-239.

[3] N. Akai and M. Sato, Decentralized leadership meets soft budget, (2005) mimeo, Hitotsubashi University and Kobe University.

[4] A. Barnett, The Pigouvian tax rule under monopoly, American Economic Review 70 (1980) 1037-1041.

[5] B.D. Bernheim, On the voluntary and involuntary provision of public goods, American Economic Review 76 (1986) 789-793.

[6] R. Boadway, K. Cuff, and M. Marchand, Equalization and the decentralization of revenueraising in a federation, Journal of Public Economic Theory 5 (2003) 201-228.

[7] R. Boadway and F. Flatters, Efficiency and equalization payments in a federal system of government: A synthesis and extension of recent results, Canadian Journal of Economics 15 (1982) 613-633.

[8] R. Boadway and M. Keen, Efficiency and the optimal direction of federal-state transfers, International Tax and Public Finance 3 (1996) 137-155.

[9] R. Boadway, P. Pestieau, and D. Wildasin, Tax-transfer policies and the voluntary provision of public goods, Journal of Public Economics 39 (1989) 157-176.

[10] R. Boadway and J.F. Tremblay, A theory of vertical fiscal imbalance, (2005) mimeo, Queen's University and Unversity of Ottawa.

[11] M. Bordignon, P. Manasse, and G. Tabellini, Optimal regional redistribution under asymmetric information, American Economic Review 91 (2001) 709-723.

[12] A.L. Bovenberg and F. van der Ploeg, Environmental policy, public finance and the labor market in a second-best world, Journal of Public Economics 55 (1994) 349-390.

[13] S. Bucovetsky and M. Smart, The efficiency consequences of local revenue equalization: Tax competition and tax distortions, Journal of Public Economic Theory 8 (2006) 119-144.

[14] T. Buettner and D. Wildasin, The dynamics of municipal fiscal adjustment, Journal of Public Economics 90 (2006) 1115-1132. 
[15] A.J. Caplan, R.C. Cornes, and E.C.D. Silva, Pure public goods and income redistribution in a federation with decentralized leadership and imperfect labor mobility, Journal of Public Economics 77 (2000) 265-284.

[16] P.A. Chiappori and I. Werning, Comment on "Rotten kids, purity, and perfection", Journal of Political Economy 110 (2002) 475-480.

[17] H. Cremer, F. Gahvari, and N. Ladoux, Externalities and optimal taxation, Journal of Public Economics 70 (1998) 343-364.

[18] M. Dahlberg and P. Pettersson-Lidbom, An empirical approach for evaluating soft budget constraints, (2003) mimeo, Uppsala University.

[19] B. Dahlby, Fiscal externalities and the design of intergovernmental grants, International Tax and Public Finance 3 (1996) 397-412.

[20] M. Dillen and M. Lundholm, Dynamic income taxation, redistribution, and the ratchet effect, Journal of Public Economics 59 (1996) 69-93.

[21] X. Freixas, R. Guesnerie and J. Tirole, Planning under incomplete information and the ratchet effect, Review of Economic Studies 52 (1985) 173-191.

[22] T.J. Goodspeed, Bailouts in a federation, International Tax and Public Finance 9 (2002) 409-421.

[23] R. H. Gordon, An optimal taxation approach to fiscal federalism, Quarterly Journal of Economics 98 (1983) 567-586.

[24] M. Köthenbürger, Tax competition and fiscal equalization, International Tax and Public Finance 9 (2002) 391-408.

[25] M. Köthenbürger, Tax competition in a fiscal union with decentralized leadership, Journal of Urban Economics 55 (2004) 498-513.

[26] J. Kornai, E. Maskin, and G. Roland, Understanding the soft-budget constraint, Journal of Economic Literature XLI (2003) 1095-1136.

[27] P. Krussel, B. Kuruscu, and A. Smith, Temptation and taxation, (2005) mimeo, Yale University.

[28] K. Mitsui and M. Sato, Ex ante free mobility, ex post immobility, and time consistency in a federal system, Journal of Public Economics 82 (2001) 445-460.

[29] Y. Qian and G. Roland, Federalism and the soft budget constraint, American Economic Review 88 (1998) 1143-1162. 
[30] J.A. Rodden, G. Eskeland, and J. Litvack (eds.), Decentralization and the challenge of hard budget constraints, MIT Press, Cambridge 2003.

[31] B. Salanie, The Economics of Contracts: A Primer, MIT Press, 1997.

[32] A. Sandmo, Optimal taxation in the presence of externalities, Swedish Journal of Economics 77 (1975) 89-98.

[33] P.G. Warr, The private provision of a public good is independent of the distribution of income, Economics Letters 13 (1983) 207-211.

[34] D.E. Wildasin, Externalities and bailouts: Hard and soft budget constraints in intergovernmental fiscal relations, working paper no. 1843, World Bank, Washington 1997.

[35] E.V. Zhuravskaya, Incentives to provide local public goods: fiscal federalism Russian style, Journal of Public Economics 76 (2000) 337-368. 


\title{
CESifo Working Paper Series
}

\author{
(for full list see www.cesifo-group.de)
}

1689 Gebhard Kirchgaessner and Silika Prohl, Sustainability of Swiss Fiscal Policy, March 2006

1690 A. Lans Bovenberg and Peter Birch Sørensen, Optimal Taxation and Social Insurance in a Lifetime Perspective, March 2006

1691 Moritz Schularick and Thomas M. Steger, Does Financial Integration Spur Economic Growth? New Evidence from the First Era of Financial Globalization, March 2006

1692 Burkhard Heer and Alfred Maussner, Business Cycle Dynamics of a New Keynesian Overlapping Generations Model with Progressive Income Taxation, March 2006

1693 Jarko Fidrmuc and Iikka Korhonen, Meta-Analysis of the Business Cycle Correlation between the Euro Area and the CEECs, March 2006

1694 Steffen Henzel and Timo Wollmershaeuser, The New Keynesian Phillips Curve and the Role of Expectations: Evidence from the Ifo World Economic Survey, March 2006

1695 Yin-Wong Cheung, An Empirical Model of Daily Highs and Lows, March 2006

1696 Scott Alan Carson, African-American and White Living Standards in the $19^{\text {th }}$ Century American South: A Biological Comparison, March 2006

1697 Helge Berger, Optimal Central Bank Design: Benchmarks for the ECB, March 2006

1698 Vjollca Sadiraj, Jan Tuinstra and Frans van Winden, On the Size of the Winning Set in the Presence of Interest Groups, April 2006

1699 Martin Gassebner, Michael Lamla and Jan-Egbert Sturm, Economic, Demographic and Political Determinants of Pollution Reassessed: A Sensitivity Analysis, April 2006

1700 Louis N. Christofides and Amy Chen Peng, Major Provisions of Labour Contracts and their Theoretical Coherence, April 2006

1701 Christian Groth, Karl-Josef Koch and Thomas M. Steger, Rethinking the Concept of Long-Run Economic Growth, April 2006

1702 Dirk Schindler and Guttorm Schjelderup, Company Tax Reform in Europe and its Effect on Collusive Behavior, April 2006

1703 Françoise Forges and Enrico Minelli, Afriat's Theorem for General Budget Sets, April 2006 
1704 M. Hashem Pesaran, Ron P. Smith, Takashi Yamagata and Liudmyla Hvozdyk, Pairwise Tests of Purchasing Power Parity Using Aggregate and Disaggregate Price Measures, April 2006

1705 Piero Gottardi and Felix Kubler, Social Security and Risk Sharing, April 2006

1706 Giacomo Corneo and Christina M. Fong, What's the Monetary Value of Distributive Justice?, April 2006

1707 Andreas Knabe, Ronnie Schoeb and Joachim Weimann, Marginal Employment Subsidization: A New Concept and a Reappraisal, April 2006

1708 Hans-Werner Sinn, The Pathological Export Boom and the Bazaar Effect - How to Solve the German Puzzle, April 2006

1709 Helge Berger and Stephan Danninger, The Employment Effects of Labor and Product Markets Deregulation and their Implications for Structural Reform, May 2006

1710 Michael Ehrmann and Marcel Fratzscher, Global Financial Transmission of Monetary Policy Shocks, May 2006

1711 Carsten Eckel and Hartmut Egger, Wage Bargaining and Multinational Firms in General Equilibrium, May 2006

1712 Mathias Hoffmann, Proprietary Income, Entrepreneurial Risk, and the Predictability of U.S. Stock Returns, May 2006

1713 Marc-Andreas Muendler and Sascha O. Becker, Margins of Multinational Labor Substitution, May 2006

1714 Surajeet Chakravarty and W. Bentley MacLeod, Construction Contracts (or "How to Get the Right Building at the Right Price?”), May 2006

1715 David Encaoua and Yassine Lefouili, Choosing Intellectual Protection: Imitation, Patent Strength and Licensing, May 2006

1716 Chris van Klaveren, Bernard van Praag and Henriette Maassen van den Brink, Empirical Estimation Results of a Collective Household Time Allocation Model, May 2006

1717 Paul De Grauwe and Agnieszka Markiewicz, Learning to Forecast the Exchange Rate: Two Competing Approaches, May 2006

1718 Sijbren Cnossen, Tobacco Taxation in the European Union, May 2006

1719 Marcel Gérard and Fernando Ruiz, Interjurisdictional Competition for Higher Education and Firms, May 2006

1720 Ronald McKinnon and Gunther Schnabl, China's Exchange Rate and International Adjustment in Wages, Prices, and Interest Rates: Japan Déjà Vu?, May 2006 
1721 Paolo M. Panteghini, The Capital Structure of Multinational Companies under Tax Competition, May 2006

1722 Johannes Becker, Clemens Fuest and Thomas Hemmelgarn, Corporate Tax Reform and Foreign Direct Investment in Germany - Evidence from Firm-Level Data, May 2006

1723 Christian Kleiber, Martin Sexauer and Klaus Waelde, Bequests, Taxation and the Distribution of Wealth in a General Equilibrium Model, May 2006

1724 Axel Dreher and Jan-Egbert Sturm, Do IMF and World Bank Influence Voting in the UN General Assembly?, May 2006

1725 Swapan K. Bhattacharya and Biswa N. Bhattacharyay, Prospects of Regional Cooperation in Trade, Investment and Finance in Asia: An Empirical Analysis on BIMSTEC Countries and Japan, May 2006

1726 Philippe Choné and Laurent Linnemer, Assessing Horizontal Mergers under Uncertain Efficiency Gains, May 2006

1727 Daniel Houser and Thomas Stratmann, Selling Favors in the Lab: Experiments on Campaign Finance Reform, May 2006

1728 E. Maarten Bosker, Steven Brakman, Harry Garretsen and Marc Schramm, A Century of Shocks: The Evolution of the German City Size Distribution 1925 - 1999, May 2006

1729 Clive Bell and Hans Gersbach, Growth and Enduring Epidemic Diseases, May 2006

1730 W. Bentley MacLeod, Reputations, Relationships and the Enforcement of Incomplete Contracts, May 2006

1731 Jan K. Brueckner and Ricardo Flores-Fillol, Airline Schedule Competition: ProductQuality Choice in a Duopoly Model, May 2006

1732 Kerstin Bernoth and Guntram B. Wolff, Fool the Markets? Creative Accounting, Fiscal Transparency and Sovereign Risk Premia, May 2006

1733 Emmanuelle Auriol and Pierre M. Picard, Government Outsourcing: Public Contracting with Private Monopoly, May 2006

1734 Guglielmo Maria Caporale and Luis A. Gil-Alana, Modelling Structural Breaks in the US, UK and Japanese Unemployment Rates, May 2006

1735 Emily J. Blanchard, Reevaluating the Role of Trade Agreements: Does Investment Globalization Make the WTO Obsolete?, May 2006

1736 Per Engström and Bertil Holmlund, Tax Evasion and Self-Employment in a High-Tax Country: Evidence from Sweden, May 2006

1737 Erkki Koskela and Mikko Puhakka, Cycles and Indeterminacy in Overlapping Generations Economies with Stone-Geary Preferences, May 2006 
1738 Saku Aura and Thomas Davidoff, Supply Constraints and Housing Prices, May 2006

1739 Balázs Égert and Ronald MacDonald, Monetary Transmission Mechanism in Transition Economies: Surveying the Surveyable, June 2006

1740 Ben J. Heijdra and Ward E. Romp, Ageing and Growth in the Small Open Economy, June 2006

1741 Robert Fenge and Volker Meier, Subsidies for Wages and Infrastructure: How to Restrain Undesired Immigration, June 2006

1742 Robert S. Chirinko and Debdulal Mallick, The Elasticity of Derived Demand, Factor Substitution and Product Demand: Corrections to Hicks' Formula and Marshall's Four Rules, June 2006

1743 Harry P. Bowen, Haris Munandar and Jean-Marie Viaene, Evidence and Implications of Zipf's Law for Integrated Economies, June 2006

1744 Markku Lanne and Helmut Luetkepohl, Identifying Monetary Policy Shocks via Changes in Volatility, June 2006

1745 Timo Trimborn, Karl-Josef Koch and Thomas M. Steger, Multi-Dimensional Transitional Dynamics: A Simple Numberical Procedure, June 2006

1746 Vivek H. Dehejia and Yiagadeesen Samy, Labor Standards and Economic Integration in the European Union: An Empirical Analysis, June 2006

1747 Carlo Altavilla and Paul De Grauwe, Forecasting and Combining Competing Models of Exchange Rate Determination, June 2006

1748 Olaf Posch and Klaus Waelde, Natural Volatility, Welfare and Taxation, June 2006

1749 Christian Holzner, Volker Meier and Martin Werding, Workfare, Monitoring, and Efficiency Wages, June 2006

1750 Steven Brakman, Harry Garretsen and Charles van Marrewijk, Agglomeration and Aid, June 2006

1751 Robert Fenge and Jakob von Weizsäcker, Mixing Bismarck and Child Pension Systems: An Optimum Taxation Approach, June 2006

1752 Helge Berger and Michael Neugart, Labor Courts, Nomination Bias, and Unemployment in Germany, June 2006

1753 Chris van Klaveren, Bernard van Praag and Henriette Maassen van den Brink, A Collective Household Model of Time Allocation - a Comparison of Native Dutch and Immigrant Households in the Netherlands, June 2006

1754 Marko Koethenbuerger, Ex-Post Redistribution in a Federation: Implications for Corrective Policy, July 2006 